Animal Health Research Institute,

Damanhour Branch.

\title{
STUDIES ON SOME BACTERIAL AND \\ MYCOTOXIN CAUSES ASSOCIATED WITH ASCITES \\ IN BROILERS AND THE SUBSEQUENT BIOCHEMICAL CHANGES
}

(With 8 Tables)

\section{By}

\section{A.A. BKHEET ; SEHAM F.G. and HANNA R.E.}

(Received at 15/12/2011)

\section{دراسات عن بعض المسببات البكتيرية والسموم الفطرية المصاحبة للاستسقاء فى دواجن التسمين والتغيرات البئية والبيوميائية المصاحبة المصنية \\ أحد ابوالمجد بخيث ، سهام فؤاد جورجى ، هناء رشاد الحوفى}

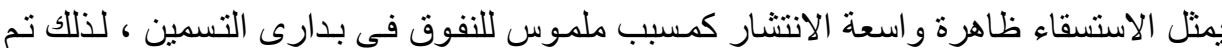

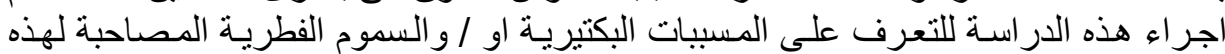

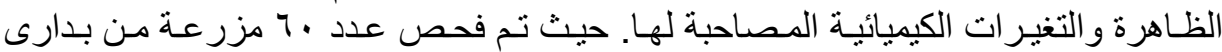

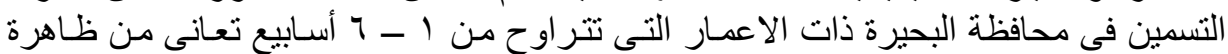

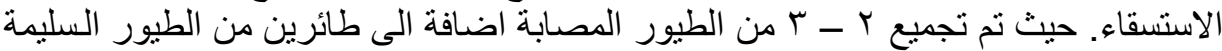

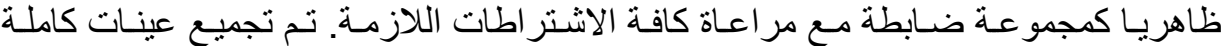

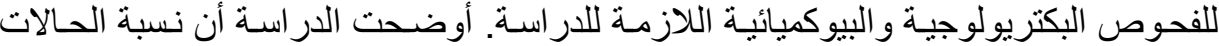

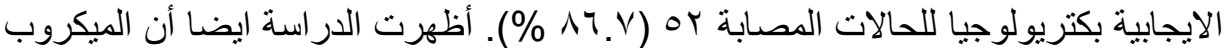

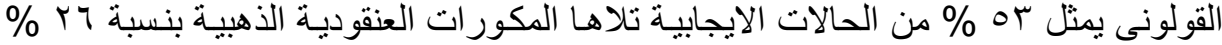

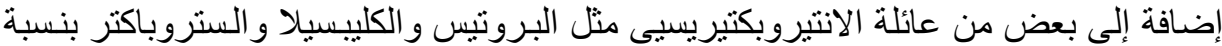

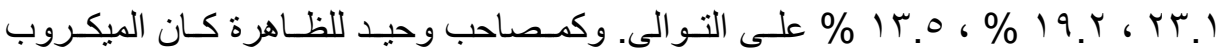

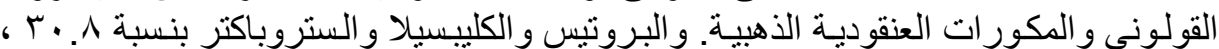

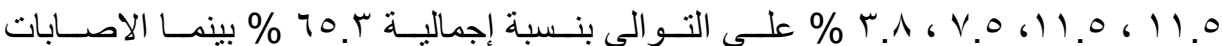

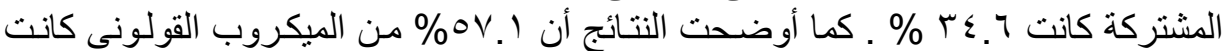

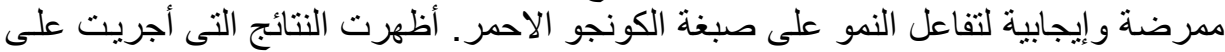

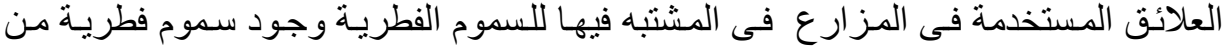

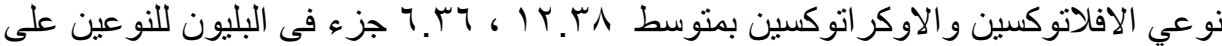

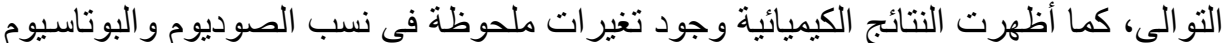

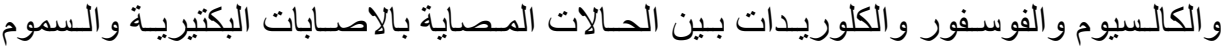

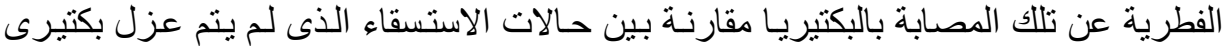


منها و الحالات السليمة ظاهريا ، كما أظهرت النتائج أيضا نفس التغير ات المعنوية في إنزيمات

الكبد ووظائف الكلى وتغيرات معنوية فى البروتين بين المجمو عات المختيات النتلفة.

\section{SUMMARY}

Ascitis is world wide syndrome in growing broiler chickens responsible for significant economic losses. This study was conducted to investigate the bacterial, mycotoxin causes or in association with ascites and the biochemical changes. 60 farms of broiler chickens aged 1-6 week with complain of ascites in some members. Random sample of ascetic birds from each were examined and sample of apparently healthy as control. Ration samples were taken when mycotoxicosis were suspected. The study claimed that $86.7 \%$ of cases were bacteriologically positive. E. coli was the predominant isolate from ascetic cases $53 \%$ of the positive cases, followed by Staph. aureus $26 \%$. Members of Enterobactereacea Proteus, Klebsiella and Citrobacter Spp. were isolated in 23.1, 19.2, $13.5 \%$, respectively, as a sole isolate from ascetic cases. E. coli, Staph. aureus, Proteus, Klebsiella and Citrobacter were in incidence of 30.8, $11.5,11.5,7.5$ and $3.8 \%$, respectively, with total incidence $65.3 \%$. Mixed infection represents $34.7 \%$. The gained E. coli were tested for pathogenicity and invasiveness as denoted $57.1 \%$ of cases were positive for Congo red. The examined ration samples of some ascetic broiler flocks revealed aflatoxin and ochrotoxins with mean value of 12.38 and 6.36 , respectively. The biochemical results revealed significant variations in electrolytes, minerals, liver enzymes and kidneys function between the bacterial \& mycotoxin, bacterial, ascetic with no infection in comparison with apparently healthy broiler chicks.

Key words: Broilers, ascites, mycotoxin.

\section{INTRODUCTION}

Ascites is the condition in which the body cavity is filled with ascetic fluid leading to mortality and carcass condemnations (Riddell, 1997). The average incidence of ascitis in broiler flocks reached to $4.7 \%$ (Nacamura et al., 1999; Soils Santos et al., 2005).

It has been suggested that right ventricular hypertrophy due to inadequate gas exchange and vasoconstriction of pulmonary arteries resulting in ascites formation (Buys and Barns, 1981). In addition, the 
increase of blood viscosity caused by high attitude, respiratory diseases and reduced oxygen transfer Cueve et al. (1974) and Huchzermeyer and De Ruyck, (1985). Moreover Baghbanzaden and Decuypere (2008); Singh et al. (2011) explained that ascites is a multi-faceted syndrome caused by interactions between physiological (O2 demand) environmental (altitude) and management (ventilation, nutrition and many diseased status) genetic factors. All seem responsible for the syndrome

A considerable number of ascitis syndromes in broiler flocks caused by microorganisms, E. coli, Salmonella Spp. and many other organisms are considered pathogenic because of their lipopolysacharide layer which triggers pulmonary vasoconstriction leading to ascites (Chapman et al., 2005). Moreover, some strains of E. coli which treated with some antibiotics lead to release of shigatoxin into blood stream of the infected individual affecting kidneys resulting in condition described (HUS) (Hemolytic Uremic Syndrome) which is principle cause of renal failure (Besser et al., 1999).

The over exposure of chicken to ammonia and dust resulted in damage to the epithelium of their respiratory tract which become deciliated and allowed inhaled pathogens especially E. coli (Oyetude et al., 1978).

Mycotoxins are produced by certain filamentous fungi in rations as a result of fungal growth (Mujoni, 2003). The synergistic effects between mycotoxins exposure and some important diseases have been suggested. Mycotoxins concern has grown during the last few decades because of their implications to human and animal health as Welles productivity and economically (Wagacha and Muthomi, 2008). Recent studies reported that additionally combined administration of Aflatoxin and other toxins resulting in synergistic toxic effects in liver and kidneys (Dimitrokalls et al., 2008). Moreover, Raja et al. (2009); Eliana et al. (2010) added that, changes in clinical blood biochemistry including inhibition of liver enzymes and levels of plasma proteins mainly albumin and globulin.

The evidence of increased dietary sodium $(\mathrm{Na}+)$ can cause ascites in chickens. Sodium in drinking water is much harmful than that in feed as broilers consumed 1.5-2.5 times more water than feed. Moreover the effects of sodium from all nutrient sources is additive in chicken (Richard et al., 1992).

Studies with regard to blood indices and biochemical variables indicated that, in the affected birds, there was a significant fall in serum 
total proteins, albumin, albumin globulin ratio (A:G), calcium and sodium. The elevation of serum alanine aminotransferase, asparate aminotransferase, alkaline phosphates and chlorine, phosphorus was reported in the ascitic birds. Also, there is haemoconcentration along with large fluctuations in serum enzyme and mineral levels in ascitic birds (Yersin et al., 1992; Julian, 1993; Dahiya et al., 2000; Daneshyar et al., 2009).

The present work was carried-out to study the ascites syndrome. Monitoring the bacterial causes or in association. The mycotoxin, in suspected cases, as cause or in association. Also, the biochemical alterations accompanied with ascitis in broiler flocks including liver and kidneys patterns and serum proteins.

\section{MATERIALS and METHODS}

I-Birds: A total number of 60 broiler flocks $1-6$ weeks of age with complain of ascitis in many birds were used. Random samples from affected birds (2-3) were representing a case, also apparentally non ascetic birds were taken as control.

II-Sampling: Birds were sacrificed by slaughtering and blood serum was firstly departed for biochemical investigations.

After scarification, birds were desiccated and samples were taken from paranchymatus organs that include heart, liver, spleen, lung and kidneys then prepared for bacteriological investigations according to Cruckshank et al. (1975).

\section{Bacteriological investigations:}

The prepared samples were inoculated on nutrient broth and seleniet $\mathrm{F}$ broth (Oxoid, 1982) after incubation at $37{ }^{\circ} \mathrm{C}$ for $18-24$ hours. Nutrient broth was inoculated on nutrient agar, blood agar and manitol salt agar. (Oxoid, 1982).

Selenite F. broth was inoculated on MacConkey agar, Eosin Methylen Blue (EMB), salmonella shegella agar (S. S. agar) (Oxoid, 1982) all were inoculated at $37^{\circ} \mathrm{C}$ for $24-48 \mathrm{hrs}$.

- Suspected colonies were examined morphologically and cellular morphology after Gram stains. Gained isolates were identified according to Cruickshank et al. (1975); Krig and Hoets (1984); Quinn et al. (2002).

- The identified E. coli strains were cultured on Congo red medium (Berkhoff and Vinal, 1988) to identify the pathogenic invasive E. coli.

Biochemical analysis was calorimetrically analyzed using biochemical kits responsible for these purposes:- 
- Sodium and Potassium were determined according to the method of Glinder and King (1972). -Inorganic phosphorus was determined according to the method implied by Dally (1972).

- Chloride was determined according to the method of Feldkamp (1974)

- Total protein was determined according to the method of Peteres (1968), while the albumin level was determined according to the method of Dumas and Bigges (1972) while the globulin level was determined mathematically using the substraction of albumin from the total protein level.

- The level of Aspartate amino transferase activity (AST) was assayed calorimetrically using the method of Reitman and Frankel (1957).

- The determination of creatinine was carried-out using the method that described by Larsenc (1972).

- Determination of uric acid was carried-out according to the method of Fosti et al. (1980).

- Detection and calculation of Aflatoxin and Ochratoxin were carried florometrically, using Florometer according to the Florometer Protocol Manual (1997).

\section{- Statistical analysis:}

The statistical analysis was carried-out using Analysis of variance test (ANOVA) for determination of the effect of different bacterial and mycotic diseases of different biochemical and haematologiocal parameters under study according to SAS (1996).

\section{RESULTS}

Table 1: Results of positive bacterial

\begin{tabular}{|c|c|c|}
\hline Result & Number & $\%$ \\
\hline positive & 52 & 86.7 \\
\hline negative & 8 & 13.3 \\
\hline Total & 60 & 100 \\
\hline
\end{tabular}

Table 2: Frequent isolates from ascitic broilers. 


\begin{tabular}{|l|c|c|c|}
\hline \multicolumn{1}{|c|}{ Isolate } & Number & $\%\left(52^{*}\right)$ & $\left(\% 60^{* *}\right)$ \\
\hline E. coli & 28 & 53.8 & 46.7 \\
\hline Proteus Spp. & 12 & 23.1 & 20 \\
\hline Proteus vulgaris & 4 & 7.7 & 6.7 \\
\hline Proteus retegri & 8 & 15.4 & 13.3 \\
\hline Klebsiella Spp. & 10 & 19.2 & 16.6 \\
\hline Klebsiella ozaena & 5 & 9.6 & 8.3 \\
\hline Klebsiella oxytocia & 5 & 9.6 & 8.3 \\
\hline Citrobacter Spp. & 7 & 13.5 & 11.6 \\
\hline Citrobacter Frundii & 3 & 5.8 & 5 \\
\hline Citrobacte Diversus & 4 & 7.7 & 6.6 \\
\hline Staph aureus & 14 & 26.9 & 23.3 \\
\hline
\end{tabular}

Table 3: Bacterial aspects of ascitis in broilers (Number of positive samples, 52).

\begin{tabular}{|c|c|c|c|c|c|}
\hline \multicolumn{2}{|c|}{ Sole cause } & \multicolumn{3}{c|}{ Mixed infection } \\
\hline Isolate & No & $\%$ & Isolate & No & $\%$ \\
\hline E. coli & 16 & 30.8 & $\begin{array}{c}\text { E. Coli }+ \text { Staph } \\
\text { aureus }\end{array}$ & 4 & 7.70 \\
\hline Staph. aureus & 6 & 11.5 & E. coli + Proteus & 4 & 7.70 \\
\hline Proteus Spp. & 6 & 11.5 & E. coli + Klebsiella & 4 & 7.70 \\
\hline Klebsiella Spp. & 4 & 7.7 & Klebsiella + Staph & 2 & 3.84 \\
\hline $\begin{array}{c}\text { Citrobacter } \\
\text { Spp. }\end{array}$ & 2 & 3.8 & $\begin{array}{c}\text { Citrobacter }+ \\
\text { Proteus }\end{array}$ & 2 & 3.84 \\
\cline { 4 - 6 } & 34 & 65.3 & $\begin{array}{c}\text { Staph. aureus }+ \\
\text { Citrobacter } \\
\text { Total }\end{array}$ & 2 & 3.84 \\
\hline Total & 34 & 18 & 34.6 \\
\hline
\end{tabular}

Table 4: Results of in vitro differentiation between pathogenic invasive E. coli

\begin{tabular}{|l|c|c|c|c|}
\hline \multirow{2}{*}{$\begin{array}{c}\text { Examined } \\
\text { Ecoli }\end{array}$} & \multicolumn{4}{c|}{ Congo Red Reaction } \\
\cline { 3 - 6 } & \multicolumn{2}{|c|}{ Positive } & \multicolumn{2}{c|}{ Negative } \\
\hline Total & $\mathrm{N}$ & $\%$ & $\mathrm{~N}$ & $\%$ \\
\hline 28 & 16 & 57.1 & 12 & 42.9 \\
\hline
\end{tabular}


Table 5: Aflatoxin and Ochratoxin in rations of some ascetic broiler flocks rations.

\begin{tabular}{|c|c|c|c|c|c|c|c|c|c|c|c|c|c|c|c|c|c|c|c|c|}
\hline Toxin & 1 & 2 & 3 & 4 & 5 & 6 & 7 & 8 & 9 & 10 & 11 & 12 & 13 & 14 & 15 & 16 & 17 & 18 & 19 & Mean \\
\hline Aflatoxin & 3 & 6.2 & 70 & 6.2 & 0 & 0 & 4 & 6 & 12 & 7 & 15 & 3 & 7 & 6 & 36 & 4 & 22 & 28 & 10 & 12.38 \\
\hline Ochratoxin & 14 & 3 & 4 & 5 & 11 & 21 & 4 & 9 & 6 & 5 & 7 & 11 & 5 & 8 & 3 & 1 & 2 & 0 & 2 & 6.36 \\
\hline
\end{tabular}

Table 6: Sodium, Potassium, Calcium, Phosphorus and Chlorine Levels among different groups.

\begin{tabular}{|c|c|c|c|c|c|c|}
\hline \multirow{2}{*}{ Group } & $\mathrm{N}$ & $\begin{array}{c}\text { Sodium } \\
\mathrm{mEq} / \mathrm{L}\end{array}$ & $\begin{array}{c}\text { Potassium } \\
\mathrm{mEd} / \mathrm{L}\end{array}$ & $\begin{array}{c}\text { Calcium } \\
\mathrm{mg} / \mathrm{dl}\end{array}$ & $\begin{array}{c}\text { Phosphorus } \\
\mathrm{mg} / \mathrm{dl}\end{array}$ & Cholorine \\
\cline { 2 - 7 } & Mean $\pm \mathrm{SEM}$ & Mean \pm SEM & Mean \pm SEM & Mean \pm SEM & Mean \pm SEM \\
\hline $\begin{array}{c}\text { Control } \\
\text { negative }\end{array}$ & 10 & $\mathrm{C}$ & $\mathrm{B}$ & $\mathrm{A}$ & $\mathrm{A}$ & $\mathrm{B}$ \\
\hline $\begin{array}{c}\text { Control } \\
\text { positive }\end{array}$ & 8 & $\mathrm{~B}$ & $\mathrm{~B}$ & $\mathrm{AB}$ & $\mathrm{AB}$ & $\mathrm{AB}$ \\
\hline $\begin{array}{c}\text { Bacterial } \\
\text { isolates } \\
\text { groups }\end{array}$ & 33 & $\mathrm{~B}$ & $\mathrm{AB}$ & $\mathrm{B}$ & $\mathrm{AB}$ & $103.91 \pm 1.93$ \\
\hline $\begin{array}{c}\text { Bacterial } \\
\text { isolates }+ \\
\text { Mycotoxins }\end{array}$ & 19 & $\mathrm{~A}$ & $143.20 \pm 1.83$ & $5.56 \pm 0.23$ & $8.17 \pm 0.17$ & $5.42 \pm 0.16$ \\
\hline
\end{tabular}

Means within the same column of different litters are significantly different at $(\mathrm{P}<0.01)$. 
Table 7: Uric acid, Creatinin, S GPT and S. GOT Levels among different groups.

\begin{tabular}{|c|c|c|c|c|c|}
\hline \multirow[t]{2}{*}{ Group } & $\mathrm{N}$ & $\begin{array}{c}\text { Uric acid } \\
\mathrm{mg} / \mathrm{dl}\end{array}$ & $\begin{array}{c}\text { Creatinine } \\
\mathrm{mg} / \mathrm{dl}\end{array}$ & $\begin{array}{c}\text { SGPT } \\
\mathrm{U} / \mathrm{L}\end{array}$ & $\begin{array}{c}\text { SGOT } \\
\text { U/L }\end{array}$ \\
\hline & & Mean \pm SEM & Mean \pm SEM & Mean \pm SEM & Mean \pm SEM \\
\hline $\begin{array}{l}\text { Control } \\
\text { negative }\end{array}$ & 10 & $\begin{array}{c}\mathrm{C} \\
7.45 \pm 0.23\end{array}$ & $\begin{array}{c}\mathrm{B} \\
0.59 \pm 0.04\end{array}$ & $\begin{array}{c}\mathrm{C} \\
52.60 \pm 2.92\end{array}$ & $\begin{array}{c}\mathrm{D} \\
120.30 \pm 8.97\end{array}$ \\
\hline $\begin{array}{l}\text { Control } \\
\text { positive }\end{array}$ & 8 & $\begin{array}{c}\mathrm{C} \\
7.88 \pm 0.30\end{array}$ & $\begin{array}{c}\mathrm{AB} \\
0.67 \pm 0.04\end{array}$ & $\begin{array}{c}\mathrm{B} \\
63.70 \pm 8.81\end{array}$ & $\begin{array}{c}C \mathrm{C} \\
137.63 \pm 20.02\end{array}$ \\
\hline $\begin{array}{c}\text { Bacterial } \\
\text { isolates } \\
\text { groups }\end{array}$ & 33 & $\begin{array}{c}\mathrm{B} \\
12.06 \pm 0.62\end{array}$ & $\begin{array}{c}\mathrm{A} \\
0.74 \pm 0.03\end{array}$ & $\begin{array}{c}\mathrm{AB} \\
66.53 \pm 5.65\end{array}$ & $\begin{array}{c}\mathrm{B} \\
206.36 \pm 16.38\end{array}$ \\
\hline $\begin{array}{c}\text { Bacterial } \\
\text { isolates }+ \\
\text { Mycotoxins }\end{array}$ & 19 & $\begin{array}{c}\mathrm{A} \\
16.94 \pm 2.29\end{array}$ & $\begin{array}{c}\mathrm{A} \\
0.77 \pm 0.03\end{array}$ & $\begin{array}{c}\mathrm{A} \\
69.13 \pm 8.11\end{array}$ & $\begin{array}{c}\mathrm{A} \\
232.21 \pm 38.06\end{array}$ \\
\hline
\end{tabular}

Means within the same column of different litters are significantly different at $(\mathrm{P}<0.01)$.

Table 8: Albumin, Globulin, Total protein Levels and Albumin/ Globulin ratio among different groups.

\begin{tabular}{|c|c|c|c|c|c|}
\hline Group & $\mathrm{N}$ & $\begin{array}{c}\text { Albumin } \\
\mathrm{mg} / \mathrm{dl}\end{array}$ & $\begin{array}{c}\text { Globulin } \\
\mathrm{mg} / \mathrm{dl}\end{array}$ & $\begin{array}{c}\text { Total } \\
\text { protein } \\
\mathrm{mg} / \mathrm{dl}\end{array}$ & $\begin{array}{c}\text { Albumin/ } \\
\text { Globulin ratio }\end{array}$ \\
\cline { 2 - 6 } & Mean \pm SEM & Mean \pm SEM & Mean \pm SEM & Mean \pm SEM \\
\hline $\begin{array}{c}\text { Control } \\
\text { negative }\end{array}$ & 10 & $\mathrm{~A}$ & $\mathrm{~A}$ & $\mathrm{~A}$ & $\mathrm{C}$ \\
& $1.46 \pm 0.07$ & $1.48 \pm 0.08$ & $2.94 \pm 0.07$ & $1.03 \pm 0.09$ \\
\hline $\begin{array}{c}\text { Control } \\
\text { positive }\end{array}$ & 8 & $\mathrm{~B}$ & $\mathrm{~B}$ & $\mathrm{~B}$ & $\mathrm{~B}$ \\
\hline $\begin{array}{c}\text { Bacterial } \\
\text { isolates } \\
\text { groups }\end{array}$ & 33 & $\mathrm{~B}$ & $\mathrm{C}$ & $\mathrm{C}$ & $1.10 \pm 0.10$ \\
\hline $\begin{array}{c}\text { Bacterial } \\
\text { isolates }+ \\
\text { Mycotoxins }\end{array}$ & 19 & $\mathrm{C}$ & $\mathrm{D}$ & $\mathrm{D}$ & $\mathrm{A}$ \\
$1.43 \pm 0.06$ & $1.41 \pm 0.08$ & $2.83 \pm 0.07$ & $\mathrm{~B}$ \\
\hline
\end{tabular}

Means within the same column of different litters are significantly different at $(\mathrm{P}<0.01)$. 


\section{DISCUSION}

Ascitis syndrome in broiler flocks have been increasing at an alarming rate and this condition has become one of leading causes of mortality and whole carcass contaminations through the world (Julian, 2002).

The present study was conducted to study the ascitis syndrome. A total of 60 broiler flocks of 1-6 week of age in Behaira province have complain of ascitis in some birds, 3-4 birds of each flock represented a sample and supplemented for the present study. Ration samples from some farms suspected to have mycotoxicosis were obtained. Results as illustrated in Table 1, revealed that $86.7 \%$ of cases were bacteriologically positive and the remnant $13.3 \%$ was negative for bacterial isolation these results agreed with the suggestion of right ventricular hypertrophy due to inadequate gas exchange and the vasoconstriction of pulmonary arteries as declared by Huchzermeyer and De-Ryck (1985). The higher incidence of bacterial association agreed with Chapman et al. (2005) who claimed that considerable number of ascitis syndrome caused by microorganisms. Also, the opinion of Oyetude et al. (1978) who claimed that the over exposure of chicken to ammonia, hypoxia and the damage of respiratory tract and deciliation allowed inhaled pathogens.

Table 2 revealed that variable detected bacterial isolates $E$. coli could be isolated in total incidence of $53.8 \%$ from positive cases and $46.7 \%$ for all examined. E. coli were detected as sole cause in $30.8 \%$. These results meet with many literatures as discussed by Oyetunde et al. (1978) who claimed that E. coli represent the main pathogen inhaled to infect respiratory tissue after deceliation of respiratory tract.

Our results agreed also with Wooley et al. (1994) who claimed that E. coli strains produce heat labile enterotoxins and lipopolysacharide which trigger pulmonary vasoconstriction leading to ascitis (Chapman et al., 2005).

Table 2, 3 revealed that Staphylococcus aureus is the second following pathogen could be isolated in ascetic flocks in incidence of $26.9 \%$ from positive bacteriological cases and as single sole isolates in $11.5 \%$.

Growth lesions of septicemia that caused by Staph. aureus infection are vascular and congestion of many organs including liver and lung and spleen (Bickford and Resenwald, 1975). These septicemic lung 
congestion leads to hypoxia and imbalance of oxygen exchange revealing to ascetic syndrome.

Table 2, 3 revealed that proteus Spp. were isolated from $33.1 \%$ of positive bacterial and represented $11.5 \%$ as sole isolate. Proteus septicemia occurs in broilers suspected of having immunologic deficiency (Randal et al., 1987). Also has been associated with respiratory diseases in chicken (Lin et al., 1993) More over (Ye et al., $1995)$ recorded, $50 \%$ mortalities in experimentally inoculated chickens with, proteus mirabilis, reisolated from lung, trachea, kidneys of chicken expressing respiratory signs, paralysis and high mortalities.

Table 2, 3 declared that Klebsiella Spp. were detected in $19.2 \%$ as associated isolate it was detected in incidence of $7.7 \%$ as sole isolate in positive bacterial Ascites cases Klebsiella is an environmental contaminant that occasionally cause mortalities in chicken. The organism has been associated with respiratory, ocular, septicemic and reproductive disease of poultry Plesser et al. (1975). Chicken inoculated with three Klebsiella pneumonia has the highest mortality as declared by (Desouky et al., 1982).

Citrobacter Spp. was detected in $13.5 \%$ of positive bacterial ascetic cases and represents a sole isolate in (2) $3.8 \%$ of positive cases. Citrobacter is a genus in the enterobacteriacae family, commonly colonized mucous membrane of respiratory and digestive tract (Saif, 2009). Citrobacter is one of many environmental bacteria that are occasionally isolated from weak chick and yalk sac infection (Lin et al., 1996) it has been isolated from liver of turkey pullet with respiratory disease (Fales et al., 1978).

Citrobacter species are known to cause a wide variety of nesocomal infection of the respiratory tract, urinary tract and the blood, hepatic, bileary and pancreatic disease that caused by Citrobacter frundii (Morco et al., 1985).

All the previously discussed bacterial pathogens may be the main cause of Ascites initiators as many of E. coli strains on the action on cilleary system of respiratory tract, pneumonia which antagonism oxygen exchange and subsequent hypoxia.

Also, the pneumonia generated due to these pathogens coalesced with bad environmental and anemia generation could be the main precursor of Ascites.

Table 4 tabulated the in vitro differentiation of invasive $E$. coli by culturing on Congo red medium. Out of 28 isolates of $E$. coli 16 (57.1) were Congo red positive. 
The growth status on Congo red is indicator for virulence, pathogenic invasive E. coli as recorded by Berkhoff and Vinal (1986). Our results lower than those reported by Moawad et al. (2008), who claimed that $83.7 \%$ of E. coli strains causing diarrhea in calves. Congo red, a simple acid dye has been used by Berkhoff and Vinal (1986) to distinguish between virulent and a virulent $E$. coli. They observed that direct correlation between the ability of certain E. coli to bind Congo red and their ability to induce septicemia infection in poultry (Gjesssing and Berkoff, 1989) However Spears et al. (1992) observed that the virulence of avian E. coli could not be absolutely predicted by the Congo red binding test.

Table 5 declared the individual mycotoxin affections of 19 examined suspected ration samples florometrically for Aflatoxin and Ochratoxin. Aflatoxin ranged from 0 up to $70 \mathrm{ppb}$ with mean value of 12.38 and Ochratoxin from 0 up to $21 \mathrm{ppb}$ with mean 6.36 these values even within permissible limit or slightly elevated but the summation and cumulative effects rendered it to be harmful (Dimitrokalls et al., 2008; Wagacha and Muthomi, 2008).

The biochemical changes in ascetic cases in comparison with control showed several significant changes. Table 6 revealed a significant increase in serum sodium $(\mathrm{Na})$, Potassium $(\mathrm{K})$ and chloride $(\mathrm{Cl})$ in all ascetic groups (Bacterial, Bacterial and mycotoxin associated and no-bacterial, non mycotoxic associated) in comparison with control non ascetic broiler. These results agreed with those reported by Richard et al. (1992); Wideman (2001); Julian (2002); Rezvan and Adel (2008).

The mono-valant minerals $\left(\mathrm{Na}^{+}, \mathrm{K}^{+}\right.$and $\left.\mathrm{Cl}\right)$ determine the dietary electrolyte balance (DEB). Sometimes referred to as strong ions due to their greater effect on acid-base balance of body fluids than divalent ions such as $\mathrm{Ca}$, Mag, PO4 or SO4 (Hooge, 2003). The increase in serum $\mathrm{Na}^{+}$ values were directly proportional to the serum $\mathrm{K}^{+}$. This results indicates that osmo-regulation of the body fluid is mainly achieved with the help of these two cations (Mustaq et al., 2005).

Water and dietary salt greatly increase plasma sodium concentration, therefore have a greater blood volume expansion, the avian blood capillaries are small and can dilate only every little to accommodate the extra blood volume produced Koike et al. (1979). In chickens a rise in plasma osmolality and/or $\mathrm{Na}^{+}$concentration stimulate plasma vasotocin (AVT) which functions as an antidiuritic hormone and might further reduce $\mathrm{Na}^{+}$excretion (Richard et al., 1992). 
Our results showed that, the increase in $\mathrm{Na}^{+}$level causes increasing body temperature probably by altering the hypothalamic thermoregulatory set prints, this would increase the body oxygen requirement and increase blood flows through the lung, increased interstitial fluid in the lung $\mathrm{Na}^{+}$induced fluid retention could compress blood capillaries and increase resistance to blood flow. Sodium affects red blood cell rigidity and size and could increase resistance to flow in the small blood capillaries.

The significant increase in sodium, potassium and chloride may be due to kidney lesions that kidneys unable to excrete $\mathrm{Na}^{+}, \mathrm{K}, \mathrm{Cl}$. These results agreed with those recorded by Siller (1981); Damron et al. (1986).

The serum calcium and phosphorus as illustrated in Table 6 showed significant decrease in ascetic broilers with bacterial and bacterial and Mycotoxins. These results agreed with those of Bailey et al. (1989) who claimed that in Ochratoxin affected birds. Moreover, Fernandez et al. (1994) reported that aflatoxins lower the serum calcium and phosphorus concentration in broilers. Lik et al. (2011) suggested that accumulation of intracellular calcium and inhibition of $\mathrm{Ca}^{+}$ATPase might be important factors for the reduce deformability of the erythrocytes of ascetic broilers.

The total protein and albumin were significantly reduced in ascetic broilers as in Table 8, similar observations were reported by Yersin et al. (1992); Enkvetchkul et al. (1993). Moreover, Biswas et al. (1995); Tankson et al. (2002), Metwally et al. (2003), Daneshyar et al. (2009); Hashem and Mahmoud (2009) claimed that, the reduction in serum protein may be adaptive physiological response to the empending loss of extracellular fluids via ascities. Meanwhile, Diaz-Cruz et al. (1996); Daneshyar et al. (2009) attribute the decrease in serum protein to the glucogeneses because this pathway was substrates rather than carbohydrates such as amino acids to produce glucose. Other explanation by Singh et al. (2011) who declared that, the decreased plasma protein could be attributed to the loss of high protein lymph from the liver or stop eating prosess.

Liver enzymes as tabulated in Table 7 revealed significant elevation. Glutamic-pyruvic transaminase (GPT) and Glutamic oxalacitic transaminase (GOT) as well as serum uric acid and creatinine which reflect tissue damage or chronic passive congestion. These results were in agreement with that reported by Enkvetcha et al. (1993); Julian (1993); Balog et al. (1994); El-Sayed (1995); Metwally et al. (2003); 
Hashem and Mahmoud (2009). The uric acid is the primary catabolic product of protein, non-protein nitrogen and purines in birds. The avian kidney excrete uric acid could be attributed to renal damage leading to decrease in the elimination rate of these waste products.

\section{REFERENCES}

Baghanzadeh, A. and Decuypere, E. (2008): Ascites syndrome in broilers physiological and nutritional perspective. Avian Pathol., 37 (2): 117-126

Baily, A. and Scout, S. (1974): Diagnostic microbiology $9^{\text {th }}$ Ed Part 2: 420-422

Baily, C.A.; Gibson, R.M.; Kubina, L.E.; Huff, W.E. and Harvey, R.B. (1989): Ochratoxin A and dietary protein. 2 - Effects on hematology and various clinical chemistry measurements. Poult. Sci. 68 (12): 1664-1671.

Balog, J.M.; Anthony, N.R.; Wall, C.W.; Dalker, R.D.; Rath, N.C. and Huff, W.E. (1994): Effect of urease inhibibitor and ceiling fans on ascitis in broilers-blood variables ascitis scores and body and organ weights. Poult. Sci. 73: 810-816.

Bath, H.; Nagar, D. and Garcia, R. (2007): Aspergillus in labbe, R.G. Garcia Ed. Gied to foodborne pathogen. Wiley and Sons NeoYork: 35-49

Berkhoff, H.A. and Vinal, A.C. (1986): Congo red medium to distinguish between invasive and non invasive Escherichia coli pathogenic for poultry. Av. Dis. 30 (1): 117-121.

Besser, R.E.; Griffin, P.M. and Shtsker, L. (1999): Escherichia coli O157: $H 7$ gastroenteritis and the hemolytic uremic syndrome. An emerging infectious disease. Ann. Rev. Med. 50: 355-367.

Bickford, A.A. and Rosenwald, A. (1975): Staphylococcal infection in chickens. Poult. Dig. July. 285-7.

Biswan, N.K.; Dalanri, M.R. and Rhomik, M.K. (1995): Ascites syndrom in broiler chickens observations on certain biochemical and pathological changes. Indian. J. Anim. Sci. 65: 1068-1072.

Buys, N.E. and Barns, P. (1981): Ascitis in broilers. Vet. Rec. 108: 266.

Chapman, M.E.; Wang, W.; Erf, G.E. and Winderman, Jr. (2005): Pulmonary hypertensive responses of broiler chickens. Poult. Sci. 65. Supp. 1: 23. 
Cotty, P.J. and Jaime, Garcia, R. (2007): Influence of climate on Aflatoxin producing Fungi and Aflatoxin contaminations Int. J. Food Microbiol.,119(1-2): 109-115.

Cruickshank, R.; Duguid, J.R.; Marmion, B.P. and Swain, R.H.A. (1975): Medical microbiology 12 Ed. Churchill Livingeston Edinburgh and New York.

Cueva, S.H.; Sillau, A.; Valenzuella, A.D. and Ploog, H. (1974): High altitude induced pulmonary hypertension and right heart failure in broiler chickens. Res. Vet. Sci. 16: 370-374.

Dahiya, J.P.; Bratia, K.C.; Mahajan, N.K.1. and Mishra, S.K. (2000): Blood indices and serum biochemical profile in ascites syndrome affected broilers. Indian Journal of Poultry Science. Year: 2001, Volume: 36: 33-36.

Dally, J.A. (1972): Colorimetric method for determination of serum inorganic phosphorus. Ckin. Chemist. 18: 263.

Damron, B.I.; Johnson, W.I. and Kelly, L.S. (1986): Utilization of sodium from sodium bicarbonate by broiler chickens. Poult. Sci. 65: 782-785.

Daneshyar, M.; Kermanshai, H. and Galian, A. (2009): Changes of biochemical parameters and enzyme activities in broiler chickens with cold-induced ascitis. Poult. Sci. 88: 106-110.

Desouky, M.L.A.; Morsy, Z.M.; Niazi, M. and Abd Allah. (1982): Experimental klebsiella infection in baby chicks. Archiv, Geflugelkunde. 46: 145-150.

Diaz-Cruz, A.; Nova, C.; Vilanueva, R.; Serret, M.; Guinzhern, R, and Pina, F. (1996): Hepatic and cardiac oxidative stress and other metabolic changes in broiler with ascitis syndrom. Poult. Sci. 75: 900-903.

Dimetrokalls, V.; Meimaroglon, D.M. and Markaki, P. (2008): Study on Ochratoxin effect on Aspergillus parasiticus growth and Aflatoxin B1 production. Food and Chimical Toxicology(46): 2435-2439.

Dumas, B.T. and Biggs, H.G. (1972): Standard methods of clinical chimestry Ed. Academic press. New york.

Eliana, N.C.; Tessari, E.K.; Anlucia, S.P.; Cardoso, D.R.; Ledoux, G.L. ana Carison, A.F. (2010): Effect of Aflatoxin B1 and Fumansin B1 on Blood Biochemical Parameters in Broiler chicken Toxins (2): 453-460. 
El-Sayed, E.M. (1995): Efficacy and side effects of some drugs against Escherichia coli and Salmonella typhimurium infections in chickens. Vet. Zag. J. 23 (3): 107-119.

Enkvetchank, R.; Bottje, W.; Anthony, N. and Moore, R. (1993): Compromised antioxidant status associated with ascitis in broilers. Poult. Sci. 72: 2272-2280.

Fales, W.H.; McCune, E.L. and Berg, I.N. (1978): The isolation of Gram negative non-fermentative bacteria from turkeys with respiratory disease. Proc. Am. Assoc. Vet. Lab. Diag. 21: 227-242.

Feldcamp, C.S. (1974): Z.Klin. Biochem., 12 :Cited from Biomerieux 6$109 \mathrm{Cl}$ Kit.

Fernandez, A.; Verdie, M.T.; Gasson, J.; Gomez, J.; Luco, D.F. and Chavaz, G. (1994): Variations of clinical biochemical parameters of laying hens and broiler chickens feed aflatoxin containing feed. Avian Path. Zaragoza Univ. Spain. 23 (1): 37-47.

Florometer Protocol Manual (1997): Afla-test and Ocra test. Doc \# GNMC9513-0: 5-9. January. 30.

Fosti, P.; Prencip, L. and Berti, G. (1980): Use of 3, 5, 2, hydroxyl benzene suphonic acid/4 aminophenazone chromogenic system in direct enzymatic assay of uric acid in serum and urine. Clin. Chem. 26 (2): 27-231.

Gjessing, K.M. and Berkhoff, H.A. (1989): Experimental reproduction of air asccultitis and septicemia by aerosol exposure of 1 day old chick using Congored positive E. coli. Avian Dis. 33: 473-478.

Glinder, E.M. and King, I.D. (1972): Rapid calorimetric determination of calcium in biological fluid with methylen blue. Am. J. Clinic. Path. 58: 376-382.

Hashem, M.A. and Mohamed, M.H. (2009): Haematobochemical and pathological studies on aflatoxicosis and treatment of broiler chickens in Egypt. Vet. Ital. Apr-Jun. Pub. Med.

Hoogs, D.M. (2003): Practicalities of using dietary sodium and potassium supplements to improve poultry performance. Page 18 in Prac. Arkansas Nut. Conf.

Huchzermeyer, E. W. and DeRuyck, A. M. (1985): Pulmonary hypertension syndrome associated with ascitis in broiler. Vet. Rec. 119: 94.

Julian, I.R. (1993): Ascitis in poultry. Review article. Avian pathology. 22: 419-454. Gross ref Medline Wet of Science. 
Julian, R.J. (2002): In F. T. W. Jordan and patison, M. (Eds) poultry diseases $5^{\text {th }}$ Ed. W. B. Sauders London U. K.: 484-496.

Koike, T.I.; Proyor, L.E. and Neldon, H.Z. (1979): Effect of saline infusion on plasma immunoreactive vasotocin in conscious chickens. Gen. Comp. Endocrinol. 37: 451-8.

Krig, N.R. and Hoet, J.G. (1984): Berg's Manual of Systemic Bacteriology. William and Wilkins Company Baltimor London.

Larsen, K. (1972): Colormetric determination of creatinine. Clin. Chem. Acta 41: 209.

Lessero.; Even shashen, A. and Bendheim, L. (1975): The isolation of klebsiella pneumoniae from poultry and hatcheries. Refu. Vet. 32: 99-105.

Lik, Z.L.; Geng, G.; Dong, S.; Xu, T.; Wand, J.; Wang, H. and Tian, Y. (2011): Increased calcium deposit and decrease $\mathrm{Ca}^{2+}$-ATPase in erythrocytes of ascitic broiler chickens. Res. Vet. Sci. 90 (3): 468-473.

Lin, A.; Shyu, C. and Shu, L. (1996): Detection of Gram negative bacterial from dead in shell chicken embryo, non-hatched eggs and newely hatched chicks. J. Chinese Soc. Vet. Sci. 22: 361-366.

Lin, M.Y.; Cheng, K.J.; Huang, L. and Tsai, W. (1993): Classification, pathogenicity and drug susceptability of haemolytic gram negative bacterial isolated from sucker dead chicken. Avian Dis. 37: 6-9.

Londman, W.J.M.; Gruys, E. and Gilkens, J. (1998): Avian amyloidosis. Avian Path. 27: 437-449.

Max well, M.H.; and Robertson, R.C. (1987): Hematological and morphological changes in broiler chickens with environmentally induced hypoxia. Res. Vet. Sci. 43: 331-338.

Mettwally, A.Y.; Sabrya, B.; Ismael, M.M. and Hegazy, A.M. (2003): Studies on ascitis in broilers. $3^{\text {rd }}$ Int. Sci. Conf. Mansoura. 427-440.

Moawad, A.A.; Salwa, M.; Thanaa, A. and El-Desouky, M. (2008): Studies on microbial causes of diarrhea in calves. Assiut Vet. Med. 54 (116): 182-205.

Morco, S.; Nchez, F.; Turabian, F.; Ndez, J.I.; Dur, N. and PerizNauarr, A. (1985): Fatal Citrobacter frundii Bronchopneumonia acquired in community in an 
uncompromised patient. Revesta Clinica Espazola Appr. 179 (6): 320 .

Murjoni, G. (2003): Chronic Aflatoxicosis in fish and its relevance to human health E Mail Cafi @Ori.nic

Mushtq, T.; Sarwor, M.; Nawaz, H.; Aslam, M. and Ahmad, T. (2005): Effect and interactions of dietary sodium and chloride on broiler starter performance (hatching to twenty-eight day of age) and subtropical summer conditions. Polut. Sci. 84: $1716-22$.

Nakamura, K.; Ibraki, Y.; Mitarai, Z. and Shibahara, L. (1999): Comparative pathology of heart and liver lesions of broilers chickens that died of ascitis, heart failure and others. Avian Dis. 43: 526-532.

Oser, B.L. (1979): Hawks. Physiological chemistry 14 Ed McGraw Hill Company LTD London.

Oxoid. (1982): Manual of culkture media ingredient and other laboratory service. Wade Road Basing Tok Hampshire UK.

Oyetude, O.O.F.; Thomson, R.G. and Carlson, H.C. (1978): Aerosol exposure of ammonia, dust and Escherichia coli in broiler chickens. Can. Vet. J. 19: 187-193.

Peters, T. (1968): Colorimetric determination of total protein in serum based on the principle of burette reaction. Clin. Chem. 14: 1147.

Plesser, O.; Even Shshin, A. and Bendhein, D. (1975): The isolation of Klebsiella pneumonia from poultry and hatchers Refu. Vet. 32: 99-105

Quinn, P.J.; Carter, M.E.; Markey, B.K.; Donell.; Donelly, W.J.C. and Leonard, F.C. (2002): Veterinary microbiology and microbial diseases. Great Britan by MBG. Book 1td, Bodmin Cornwall, U. K.

Raja, K. and Chidambaram, B. (2009): Histopathological changes in broiler chicken feed Aflatoxin and cyclopiazonic acid Vet. Arshieve, 79(1): 31-40

Randall, C.J.; Lees, G.A.; Pepin, G. and Ross, H.M. (1987): An unused intracellular infection in ducks. Avian Pathol. 16: 479-491.

Reitman, S. and Frankel, S. (1957): A colorometric method for the determination of serum glutamic oxalacitic and glutamic pyruvic transaminase. American J. of Clinical Pathology. 28: $56-63$. 
Rezvan, K. and Adel, F. (2008): The study of relatin between normal and higher than standard concentration of sodium of drinking water in ascitis syndrome declaration in broiler chickens. Internat. J. Poult. Sci. 7 (1): 89-91.

Richard, J.; Julian, L.J.C. and Steve, L. (1992): The effect of dietary sodium on right ventricular failure-induced ascitis, gain and fat depression in meat-type chickens. Con. J. Vet. Res. 56: 214-219.

Riddel, C. (1997): Developmental, Metabolic and other non infectious disorders: $913-950$ in diseases of poultry $10^{\text {th }}$ Ed by calnk, Ames, lowa state university press USA

Saif, Y.M. (2009): Diseases of poultry. $12^{\text {th }}$ Ed BlackWell Publish.

SAS. (1996): Statistical Analysis System. SAS Inst. Inc., Cary, NC, USA.

Siller, W.G. (1981): Renal pathology of the fowl. A review. Avian Pathol. 10: 187-262.

Silva, I.M.; Dala, N. and Buches, M. (1988): Effect of feed on the incidence of ascitis in broilers reared at low attitude. Avian Disease. 32: 376-378.

Singh, P.K.; Pallav Shekhar and Kausha Kumar (2011): Nutritional and manage mental control of ascites syndrome in poultry International J.of Livestock production Vol. 2 (8): 117-123

Solis, de los Santos, R.G.; Tailer, M.R.; Farnail, I.M. and Anthro, R. (2005): Hypothermic hypoxia in ascitis resistance and susceptable broiler genetic lines influences gut morphology. Poult. Sci. 84: 145-148.

Spears, K.R.; Wooley, R.E.; Brown, J. and Nolan, L.K. (1992): Failure of the Congo red dye uptake test to discriminate between virulent and a virulent avian E. coli. Avian Dis. 36: 1012-1014.

Tankson, I.D.; Thaylon, I.P. and Vizzier, T. (2002): Biochemical and immunological changes in chickens of pulmonary hypertension syndrome caused by enterococcus faecales. Poult. Sci. 81: 1826-1831.

Wagasha, J.M. and Muthomi, J.W. (2008): Mycotoxins problem in Africa current Implication to food saifty and health and possible management strategies Int. J. Food Microbiol. May 10: $124-(1-2)$

Wideman, R.F. (2001): Pathophysiology of heart-lung disorders: Pulmonary hypertension syndrome in broiler chickens. Worled's Poultry Science Journal. 57: 289-307. 
Wooley, R.E.; Brown, J.; Gibbs, P.S.; Nolan, L.K. and Turner, K.R. (1994): Effect of normal intestinal flora of chicken on colonization by virulent colicin-V-producing avian Escherichia coli. Avian Dis. 38: 141-145.

Ye, S.; Xu, S.; Zhang, L.M.; Wong, Z.; Jiang, L.; Huang, Y.; Zhang, Z.; Wang, J. and Jiang, W.M. (1995): Investigation of proteus infection in chicken, Chinese. J. Vet. Sci. Tech. 25: 14-15.

Yersin, A.G.; Huff, W.E.; Kubena, L.; Elssalde, M.H.; Harvey, R.B.; Witzel, D.A. and Giroir, L.E. (1992): Changes in haematological blood gases and serum biochemical variables in broilers during exposure to simulated high altitude. Avian Dis. 36: 189-196. 